\title{
AZ ÓVODAPEDAGÓGUS- ÉS TANÍTÓKÉPZÉS HAZAI VÁLTOZÁSAI - A PATAKI PÉLDA
}

\author{
KELEMEN JUDIT \\ az Eszterházy Károly Főiskola Comenius Karának \\ föiskolai docense \\ kelemen@ekfck.hu
}

A tanulmány az Eszterházy Károly Föiskola Comenius Karán történt tantervi, képzési és gyakorlati képzési fejlesztésekröl ad átfogó képet a tanitó- és óvodapedagógus alapszak vonatkozásában. A MAB véleményére való reagálás mellett képzési és gyakorlati képzési fejlesztések is történtek a TÁMOP 4.1.2.B. pályázat jóvoltából. A gyakorlati képzés megújítását elökészitoo tanulmányok írása, C-SWOT analizis, valamint országos kitekintés elözte meg. A munkálatok legföbb elemeinek bemutatása, a fejlesztések összefoglaló áttekintése képezi a tanulmány gerincét.

\section{Előzmények}

Sárospatakon jelenleg tanító- és óvodapedagógus alapszak (BA) működik. Az Eszterházy Károly Főiskolához való csatlakozás (2013) számos elöremutató változást eredményezett a „Pataki Képző” életének különféle területein - jelen tanulmány e szük két tanév képzésfejlesztési eredményeit foglalja össze a két alapszak területén. E fejlesztéseket két esemény indukálta: a 2012 tavaszán zajló párhuzamos akkreditáció tanulságai és elvárásai, valamint a 2014. január - 2015. június közt zajló TÁMOP 4.1.2.B.2-13/1-2013-0005 „Együttmüködés az észak-magyarországi pedagógusképzés minőségi megújításáért" program által nyújtott lehetőségek.

A párhuzamos akkreditáció az ország valamennyi tanító- és óvodapedagógus-képző intézményének a 2007-2011 közötti időszakban való működését vizsgálta - a Comenius Kart érintően az alábbi kritikai észrevételeket tette a két szak mintatanterveivel kapcsolatban:

- a képzés koherenciáját veszélyeztető tantárgyi szétaprózottság (mindkét szak);

- indokolatlanul magas kurzus- vagy tanegységszám (mindkét szak);

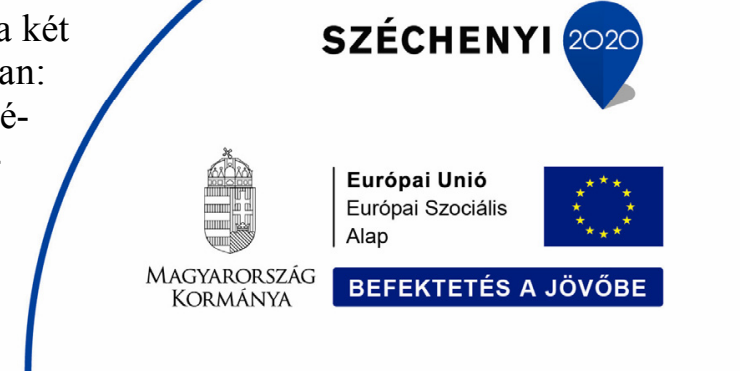


- $\quad$ egykredites tanegységek léte (mindkét szak);

- kevés közös alapozó és választható tárgy a két szakon.

Mindkét alapszakunk számára új mintatantervet készítettünk, melyekben törekedtünk a MAB elvárásinak teljesítésére. $\mathrm{S}$ bár a MAB észrevételek nem vonatkoztak a gyakorlati képzési modulokra, az oktatói közösség érezte úgy, hogy indokolt a struktúra újragondolása, korszerüsítése. A TÁMOP 4.1.2.B. pályázat támogatta ezt a szándékot, valamint - szintén mindkét szakunk vonatkozásában - a szükséges humánerőforrás fejlesztését is.

\section{Új mintatantervek kialakítása}

A párhuzamos akkreditáció megállapításaira való reagálásként az 2013/14-es tanév őszi szemeszterére új mintatanterv került kidolgozásra és bevezetésre az első évfolyamos hallgatók számára. Az alapkoncepció a pedagógusképzési területbe tartozó két alapszak szakmailag megalapozott azonos tartalmaira vonatkozott, hogy ezek közösen szerepeljenek a programban. Ennek eredményeként az első félév teljesen megegyezik mindkét szakon, támogatva a párhuzamos tanulmányok iránt érdeklődő hallgatók tanulmányait is. A továbbiakban egy teljes, minden tekintetben megújult szerkezetủ és szemléletü mintatanterv kialakításán fáradoztunk. A tartalmat illetően figyelembe vettük az új NAT által preferált azon területeket, amelyek az oktatáspolitika fókuszának megfelelően, új elemként kerültek a dokumentumba, a szerkezeten belül pedig megszüntettük az egykredites tanegységeket.

Kis létszámú oktatói karunk a tantárgyfelelösi MAB elvárásokat nem képes önállóan teljesíteni, a székhelyen pedig közben meghirdetésre került mind a tanító, mind az óvodapedagógus alapszak, ezért a megújult mintatantervbe pataki és egri tantárgyfelelősök kerültek megnevezésre, bizonyos esetekben pedig (az intézményi tantárgyfelelősi optimalizáció elveit szem előtt tartva) már létező, az EKF más karain oktatott tanegységek átvételére került sor.

Korábbi mintatantervünk sarokszámai minden tekintetben megfeleltek a képzési és kimeneti követelményben megfogalmazottaknak, ezért ebből a szempontból csupán apró finomításokra volt szükség: emeltük az értelmiségi léthez és a társadalomtudományi müveltséghez szerintünk nélkülözhetetlen tanegységek számát, valamint éltünk a választható tantárgyak átcsoportosításának lehetőségével. Az Eszterházy Károly Főiskolához történő csatlakozás pozitív hozadékaként színesedett a kötelezően, illetve szabadon választható modulok köre. Ennek eredményként a tanító szakon mind a tíz választható múveltségi terület tantárgyaihoz sikerült megfelelő szakképzettséggel és minősítettséggel rendelkező tantárgyfelelősöket találnunk. Így a székhely és a telephely képes akár valamennyi választható müveltségterületi képzést egyidejüleg indítani. (Érdeklődő hallgatóink számára igény esetén akár kettőt 
is hirdethetünk.) A tanító alapszak (240 kredit) végső szerkezetének lényegét az alábbiakban foglaljuk össze:

- Közös alapozó ismeretek: 4 tantárgyi blokk / 22 tanegység / 44 kredit;

- Szakmai elméleti modul: 7 tantárgyi blokk / 45 tanegység / 94 kredit;

- Kötelezően választható differenciált szakmai ismeretek az intézmény egyedi jellegét adó ismeretkörökböl: 1 tantárgyi blokk / 5 tanegység / 10 kredit; 1-1, egyenként 5 tanegységből álló, 10 kredites modult kell választani a hallgatóknak a felkínált 9 modulból;

- Kötelezően választható müveltségterületi modulok (VMT); 5-6. osztály: 1 tantárgyi blokk / 7-12 tanegység / 23 kredit; 1-1, egyenként 7-12 tanegységből álló, 23 kredites modult kell választani a hallgatóknak a felkínált 10 modulból;

- Szabadon választható tantárgyak (14 kredit);

- Záróvizsga modul (15 kredit);

- Szakmai gyakorlati modul (40 kredit);

Az óvodapedagógus alapszak esetében (180 kredit) az alábbiaknak megfelelően alakult az új mintatanterv struktúrája:

- Közös alapozó ismeretek: 4 tantárgyi blokk / 18 tanegység / 36 kredit;

- Szakmai elméleti modul: 7 tantárgyi blokk / 30 tanegység / 60 kredit;

- Kötelezően választható differenciált szakmai ismeretek az intézmény egyedi jellegét adó ismeretkörökből: 6 tantárgyi blokk / 6 tanegység / 12 kredit;

- Speciális programok modul: 10 tantárgyi blokk / 38 tanegység / 16 kredit; 2-2, egyenként 4 tanegységből álló, 8 kredites modult kell választani a hallgatóknak a felkínált 9 modulból;

- Záróvizsga modul (10 kredit);

- Szakmai gyakorlati modul (32 kredit);

- Szabadon választható tantárgyak (14 kredit).

A MAB elvárásoknak megfelelően kialakított és hangsúlyozott közös tanegységtartalmakat a következők:

- Alapozó ismeretek: 16 tanegység / 32 kredit;

- Szakmai törzsanyag; szakmai elméleti modul: 13 tanegység / 26 kredit;

- Differenciált szakmai ismeretek: 2 tanegység / 4 kredit;

- Speciális programok: 38 tanegység / 76 kredit;

- Szabadon választható tárgyak: 8 tanegység / 16 kredit;

- Kötelező tárgyak (alapozó ismeretek, szakmai törzsanyag, differenciált): 31 tanegység / 62 kredit;

- Választható tárgyak (speciális programok, szabadon választható): 46 tanegység / 92 kredit.

Összesen: 77 tanegység / 154 kredit 
A speciális programok esetében különösen kiemelkedő a közös tanegységek számossága, a közösen oktatható tananyagtartalmak föként ezen a területen jutottak érvényre. A tanító szak differenciált szakmai ismereteinek tíz kreditjéből az első négy félévre érvényes nyolc kredit adja az óvodapedagógus szak speciális programjait, míg a modulok előfeltételhez nem kötött tanegységeit önálló, szabadon választható tárgyként is meg tudjuk hirdetni. A kellő kínálat biztosításának szándéka mellett a székhely és telephely eltérő humánerő forrása (speciális képzettség és mindenkori oktatói kapacitás) is indokolja a rugalmas programhirdetés lehetőségét.

\section{Képzésfejlesztési programok}

A TÁMOP 4.1.2.B. program keretében lehetőségünk volt további szakmai elképzelések kidolgozására is. A témakörök kialakítását részben a környezeti igények (inkluzív nevelés, roma kultúra) és lehetőségek (lovassport, bábjáték, helyi kulturális étékek) felmérése és felhasználása indukálta, részben pedig a megújult NAT (mindennapos testnevelés, mindennapos múvészeti nevelés) és az információs társadalom folyamatosan módosuló elvárásaihoz igazodtunk. A pályázat másfél éve alatt az alábbi feladatok valósultak meg az óvodapedagógus és tanítóképzés fejlesztésének szándékával:

- Az inkluzív nevelés moduljának átalakítása - az inkluzív nevelés koncepciójának kidolgozása workshop keretében; képzési szerkezet kialakítása; tantárgyleírások elkészítése; a dokumentáció kari tanács elé terjesztése.

- A roma kultúra moduljának kidolgozása; közmủvelődési műhely és tolerancia szakkollégium előkészítése - féléves tolerancia kurzus, a kapcsolódó tematikák kidolgozása; az oktatáshoz szükséges anyagok (segédanyagok, prezentációk) kidolgozása; esettanulmányok készítése; drámamühely mint szakkollégium tantervének, tantárgyi programjának az elkészítése; konkrét drámapedagógiai foglalkozások tervének leírása.

- Információs műveltség és médiabefogadás, Pedagógiai kutatómühely - Tabletre (iPad) adaptált alsó tagozatos munkafüzetek készítésének módszertani kézikönyve; iPad-re készült alsó tagozatos alkalmazások gyüjteménye az alkalmazások módszertani elemzésével; mintaalkalmazás készítése: munkafüzet alsó tagozatos szövegértés fejlesztésére; munkafüzet kipróbálása pedagógiai kísérlettel, kutatás összegzése, módszertani ajánlások elkészítése.

- Az óvópedagógus és tanítói tevékenység IKT elemeinek kidolgozása - óvodapedagógus/tanító professziogram IKT összetevőinek elemző vizsgálata; statisztikai elemzések a NOLDUS felhasználásával; az óvodapedagógusi és tanítói munkában feltárt IKT elemek meghatározása és elemzése; feltárt IKT elemek elsajátításának módszertani lehetőségei, statisztika NOLDUS felhasználásával; az eredmények beépítése az óvó- és tanítóképzés programjába. 
- A fejlesztő bábjáték pedagógiájának adaptálása - az alkalmazott bábjáték ismeretanyagának beemelése az óvó- és tanítóképzés tantervi hálójába; tantárgyi programok készítése; módszertani útmutató és oktatási segédanyagok készítése; továbbképzési program (nem hivatalos bábjátékos) dokumentációjának összeállítása.

- A lovassport fejlesztő hatásai kisgyermekkorban program kidolgozása - tanegység-leírás és ehhez kapcsolódó oktatási segédanyag készítése; szakmai tapasztalatszerzés lovas táborban; fotó- és videoanyag készítése; lovas kultúrát népszerüsítő fórum szervezése; a tevékenység kutatás-fejlesztési elemeinek és munkafolyamatának elemzése, értékelése, záró következtetések és javaslatok a program kari/föiskolai beindítására, ajánlás más intézményeknek.

- A helyi kulturális örökség szerepe a pedagógiai munkában - tanulmányok és tantárgyleírások készítése, kiállítás.

- Tanító- és óvóképzés megújítása, mentor program - gyakorlati képzési programkidolgozás: az óvodapedagógus és a tanító szak jelenlegi jellemzőinek vizsgálata, kritikája, egybevetése \{karon, országosan\}; az óvodapedagógus és tanító szakos gyakorlati képzés szerkezetének megújítása, kidolgozása \{tantervi korszerüsítéssel\}; a gyakorlati képzéshez kapcsolódó dokumentumok elkészítése \{útmutató, igazoló lapok, egyéb ürlapok/feladatlapok\} félévente és az összefüggő gyakorlati képzésre vonatkozóan; pedagógiai tervek gyüjteményének létrehozása; pedagógiai-pszichológiai támogatás; müveltségterületi támogatás, székhely-telephely koordináció.

- Továbbképzési és módszertani programok hiányterületekre - két-két pedagógus-továbbképzési kurzus kidolgozása óvodapedagógus és tanító szakra, ebből egy kipróbálása. Az új tanegységek a következők: Komplex müvészeti nevelés 6-10 éves korosztályban. Komplex müvészeti projektek tervezése a különféle mủvészetek mozaikszerü összeszervezésével; A heti 5 órás testnevelésben megjelenő új tartalmak, lehetőségek az 1-4. osztályban; Inkluzív nevelés az óvodában - a befogadó pedagógus; Fejlesztési lehetőségek az óvodai mozgásos tevékenységekben.

\section{A gyakorlati képzés megújítása}

A tanító- és óvóképzés megújítása gondolatkörhöz kapcsolódóan tehát mindkét alapszakunk gyakorlati képzésének megújítását is célul tüztük ki. A gyakorlati képzési modul megváltoztatásának szakmai előkészítéseként négy tanulmány készült:

- Jaskóné Gácsi Mária: A gyakorlati képzés szemléleti hátterének és kereteinek meghatározása. A pedagógus-idea.

- Sontráné Bartus Franciska: Az óvodapedagógus és tanító ideát szolgáló gyakorlati képzés fő jellemzőinek meghatározása, alapelvek. 
- Kelemen Judit: Az óvodapedagógus szakos gyakorlati képzés jelenlegi jellemzőinek vizsgálata, kritikája, országos és kari jellemzők egybevetése.

- Marcziné Fazekas Erzsébet: Az EKF CK tanító szak gyakorlati képzésének helyzete és a képzés megújítására tett javaslatok, egybevetve az ideát szolgáló alapelvekkel.

E négy tanulmány egy, a TÁMOP pályázathoz kapcsolódó produktumként rövidesen napvilágot látó tanulmánykötetben elérhetővé válik a részletek iránt érdeklődők számára ${ }^{1}$. A két utóbbi tanulmány egy-egy országos kitekintést, valamint az erre épülő komparatív elemzéseket is magában foglalja - jelen írás a tanító alapszak vonatkozásában teljes egészében Marcziné Fazekas Erzsébet tanulmányára támaszkodik.

Az előkészítő tanulmányokban javasolt módosításokat számos szakmai egyeztetés követte, majd megszületett mindkét alapszakunk új gyakorlati képzési modulja. A folyamatról és a végeredményröl Stóka György „A szakmai gyakorlati modul az óvó- és tanítóképzés új tantervi rendszerében" címü írása számol be, amely szintén olvasható lesz a fent említett tanulmánykötetben.

Az országos kitekintéseket vizsgáló mindkét tanulmány egy szigorú C-SWOT analízissel kezdődik, melynek során összegzi az adott szakra vonatkozó gyakorlati képzés módosítandó elemeit. Az ország képzőintézményeinek gyakorlati képzési szerkezete, valamint (ahol lehetséges volt) a tartalmi elemek vizsgálata és összehasonlítása képezi a tanulmányok egyik legfontosabb részét, hisz ezek alapján kerültek összefoglalásra általánosnak vagy épp egyedinek tekinthető képzési megoldások. A Comenius Kar számára is hasznosnak vélt, eddig nem alkalmazott ötletek beemelésére, illetve egyéb módosító javaslatok megfogalmazására is vállalkozott a két szerző.

Tekintsük át - elsőként - a tanító alapszakra vonatkozó lényeges észrevételeket!

\begin{tabular}{|c|c|}
\hline \multicolumn{2}{|c|}{ KORLÁTOK } \\
\hline $\begin{array}{l}\text { - a jelenlegi gyakorlóhelyen a mentorok s } \\
\text { bevonását a gyakorlati képzésbe; } \\
\text { — új oktatók alkalmazása csak korlátozott } \\
\text { oktatók nyugdíjba vonulásával lehetség } \\
\text { tantárgypedagógusok nem tudják tapasz }\end{array}$ & $\begin{array}{l}\text { záma nem teszi lehetővé több osztály } \\
\text { an, vagy majd a nyugdíjkorhatárhoz közeli } \\
\text { es, így a nagy tapasztalattal rendelkező } \\
\text { talataikat átadni a fiatal kollégáknak. }\end{array}$ \\
\hline ERŐSSÉGEK & GYENGESÉGEK \\
\hline $\begin{array}{l}\text { - a kis létszámú hallgatói csoportok } \\
\text { közvetlen kapcsolatot tesznek lehetővé } \\
\text { oktató és hallgató, mentor és hallgató } \\
\text { között; }\end{array}$ & $\begin{array}{l}\text { - } \text { a tanító szak gyakorlati képzésének kari } \\
\text { szervezése, irányítása nem megfelelö; } \\
\text { - } \\
\text { a gyakorlati képzés tantervi hálója } \\
\text { és útmutatója nincs összhangban; }\end{array}$ \\
\hline
\end{tabular}

${ }^{1}$ Bibliotheca Comeniana XIX. - különszám, 2015 (megjelenés alatt) 
- a helyi gyakorlóhelyen a gyakorlati képzés szervezését végző kolléganő következetes, jó szakember;

- jó a kapcsolat a gyakorlóhely pedagógusaival;

- lelkes, megújulni akaró szakvezetők vállalták a gyakorlati képzéssel járó feladatokat;

- kiváló tárgyi feltételekkel rendelkező helyi gyakorlóhelyünk van;

- jók a helyi és környékbeli adottságok (speciális szakmai tapasztalatok megszerzésére is alkalmas helyi és környékbeli iskolák: Erdélyi János Általános Iskola és Kollégium, Makkoshotyka 100\% roma osztályok, Hercegkút német nemzetiségi iskola, Sátoraljaújhely szlovák nemzetiségi iskola stb.).
- a föiskolai oktatók nem egységesek a tanórára felkészítés követelményeiben és a tanórák értékelésében;

- a hallgatói tanítások előkészítésén nem jellemző az oktatási folyamat célelméleti megközelítése;

- hallgatóink föleg frontális osztálymunkát szerveznek tanításaik során;

- a hallgatói tanítás önértékelése, elemzése (reflexiója) többnyire csak felidéző, az órai tevékenység leírására hagyatkozik;

- a tanítási órák tantermi bemutatásához, elemzéséhez rendelkezésre álló videofelvételek elavultak (10-15 évesek);

- hallgatóink a pedagóguspálya megkövetelte feladatoknak csak egy részére kapnak felkészítést;

- a jelenlegi gyakorlóhely pedagógusai még nem gyakorlottak a mentori, szakvezetői tevékenységben;

- nincs közös, együttes tapasztalatcsere a tantárgypedagógusok és a gyakorlóhely szakvezetöi között;

- kevés a lehetőség (az óra) a hallgatók számára az ún. „készségtárgyak” tanítására;

- hallgatóink nem mindent tantárgyat tanítanak a négy év során;

- a gyakorlati képzés tanegységeinek elnevezése nem kifejező (túl általános);

- a nem helyi gyakorlóhely szakvezetői nem kapnak kellő felkészítést a hallgatói gyakorlatok vezetéséhez, értékeléséhez, dokumentálásához;

- a hallgatók konfliktuskezelő kommunikációja alacsony színvonalú, didaktikai kultúrája szegényes, reflexiójuk nem megfelelö;

- a zárótanítások nem kapnak szerepüknek megfelelő hangsúlyt; 


\begin{tabular}{|c|c|}
\hline & 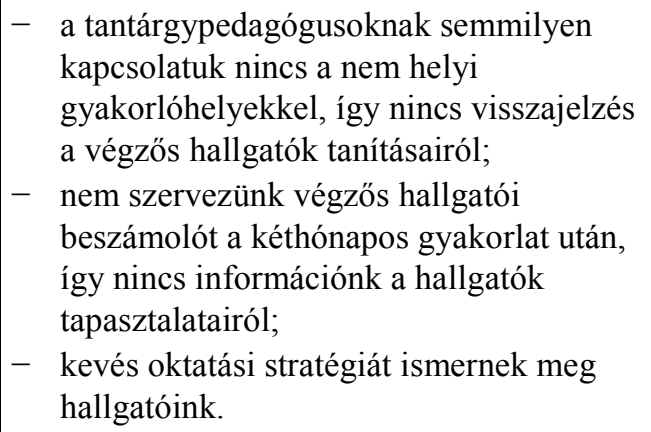 \\
\hline LEHETŐSÉGEK & VESZÉLYEK \\
\hline $\begin{array}{l}\text { — az új tantervi háló és az EKF karaival } \\
\text { való együttmüködés módszerbeli } \\
\text { megújulást tesznek lehetővé; } \\
\text { _ } \\
\text { a pályázat (melynek keretében ez a } \\
\text { tanulmány is készül) megvalósíthatóvá } \\
\text { teszi új oktatók bevonását a föiskolai, } \\
\text { egyben a gyakorlati képzésbe; } \\
\text { _ } \quad \text { a pedagóguspálya modell } \\
\text { bevezetésével javulhat a hallgatói } \\
\text { motiváció; } \\
\text { - } \quad \text { egységesebb hallgatói mentorálás } \\
\text { várható a jelenlegi mentorképzésben } \\
\text { részt vevő pedagógusok bevonásával; } \\
\text { - a környező iskolák: a helyi kisegítő } \\
\text { iskola, valamint a nemzetiségi iskolák, } \\
\text { osztályok különleges gyakorló terepet } \\
\text { kínálnak. }\end{array}$ & 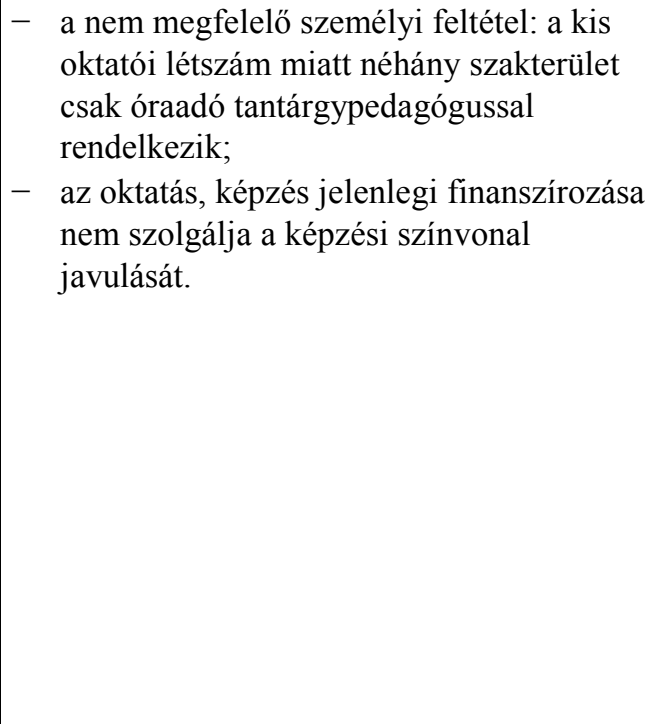 \\
\hline
\end{tabular}

1. ábra: A tanító alapszak C-SWOT analízise 2014 tavaszán (Marcziné, 2015)

Előrelépés, azaz a képzés megújítása szempontjából elsősorban a gyengeségeket kell alaposan megvizsgálnunk, hisz ezek mutatják az elöttünk álló feladatokat. Mint látjuk, a kritikus észrevételek egyaránt érintik a szervezési tennivalókat, az eszközök/tárgyi feltételek kérdéskörét, valamint a tényleges tantervi hiányosságokat. A gyakorlati képzési modul modernizálása szempontjából azonban csak az utóbbi körbe sorolható észrevételek tartoznak (hallgatóink a pedagóguspálya megkövetelte feladatoknak csak egy részére kapnak felkészítést; kevés a lehetőség \{az óra\} a hallgatók számára az ún. „,készségtárgyak” tanítására; hallgatóink nem mindent tantárgyat tanítanak a négy év során; a gyakorlati képzés tanegységeinek elnevezése nem 
kifejező \{túl általános\}; a zárótanítások nem kapnak szerepüknek megfelelő hangsúlyt; nem szervezünk végzős hallgatói beszámolót a kéthónapos gyakorlat után, így nincs információnk a hallgatók tapasztalatairól).

Az országos helyzet bemutatása során a képzőintézmények honlapjain elérhető gyakorlati képzési mintatantervek alapján a képzési szerkezet, a szervezeti formák, a feladatok félévekre bontott ütemezése, a kreditérték és óraszám, valamint az ellenőrzés-értékelés módja hasonlítható össze. Mivel nem állt minden esetben rendelkezésre a gyakorlati képzési útmutató, alapos, körültekintő elemzésre nem nyílt mód. Azt azonban általánosságban megállapítható volt, hogy az egyes gyakorlattípusok elnevezése nem elég kifejező - csak ritkán mutatják alcímek a gyakorlat részletes tartalmát.

A gyakorlati képzési mintatantervekben olykor kifejezetten egyszerü felépítéssel találkozunk, mindössze 3-4 szervezeti forma megjelenítésével. Ugyanakkor részletes tananyagtartalmat feltüntető, kifejezetten terjedelmesnek tekinthetö gyakorlati képzési modul is szerepel a vizsgált anyagban. Az előbbiben könnyen eligazodik a gyakorlati képzés minden szereplöje, az utóbbiban pedig egyértelmü az elöírt tantárgyi kötelezettség mibenléte. Ugyanakkor olyan, egyedinek tekinthető elnevezések is akadnak a szakmai gyakorlati modulokban, amelyeket csak egy-két intézmény használ.

A tanulmány szerzője aggályát fejezi ki abban a vonatkozásban, hogy a korszerü nevelésfelfogás eszméje vajon elég hangsúlyos szerepet kap-e a gyakorlati képzés rendszerében, hisz a képzőintézmények többségének tanegység-elnevezéseiben ez nem tükröződik. Az egyedileg használt tanegységnevek közt azonban néhány már elnevezésében is utal a neveléssel kapcsolatos tennivalókra (nyári nevelési gyakorlat; egyéni nevelési gyakorlat; pszichológiai hospitálás; nyári szakmai gyakorlat).

Az óra- és kreditszámok összehasonlításának eredményeként megállapítható, hogy általában 30 munkaóra (ebből 15 kontaktóra) 1 kredit, és többnyire a $\mathrm{KKK}^{2}$ ban megadott kreditértéknek megfelelően kerülnek megállapításra a szakmai modulok kreditszámai. Több intézmény bizonyos tennivalókat kritériumkövetelményként ír elő (kredit nélkül, kötelező teljesítéssel), amely ugyan látens óraszámnövelésnek tekinthető, de maga a szerző sem tartja elegendőnek a KKK által elöírt időmennyiséget a gyakorlati képzésre. Sárospatakon pedig még ezt a lehetőséget sem használjuk ki maradéktalanul (40 kredit/595 óra a lehetséges 50 kredit/750 óra helyett). Az egyes tevékenységek értékelésének módja és hozzárendelt kreditértéke is nagyon eltéró a vizsgált tantervekben.

$\mathrm{Az}$ egyes tevékenységek elnevezése országos viszonylatban nem tekinthető sem egységesnek, sem kifejezőnek. A szerző minden gyakorlattípussal kapcsolat-

\footnotetext{
${ }^{2}$ Képzési és kimeneti követelmény, tanító alapképzési szak URL: http://net.jogtar.hu/jr/gen/hjegy_ doc.cgi?docid=A0600015.OM Letöltés ideje: 2014. december 11.
} 
ban kifejti véleményét, javaslatot téve az általa szerencsésebbnek vélt névhasználatra. Szintén általános megállapításként összegzi gondolatait arról, hogy hallgatóink nem kapnak maradéktalan felkészítést a teljes körü pedagógusi munkához.

Ezt követően megoldási javaslatokat fogalmaz meg a gyakorlati képzés megújítására az általa felvetett kérdések, a felvázolt pedagógus idea (Jaskóné, 2015) és a C-SWOT analízis alapján. Gondolatai az alábbiakban összegezhetőek:

- a gyakorlati képzés teljes óraszámának növelése;

- az egyéni tanítások óraszámának növelése;

- valamennyi tanóratípus kipróbálása gyakorló iskolai környezetben;

- a tanítási órák típusának racionális elosztása a gyakorlat során;

- a szervezeti formák módosítása;

- a tanegységek elnevezéseinek kifejezőbbé tétele;

- felkészítés a pedagógus szerepkör egészére.

\section{KORLÁTOK}

- a gyakorlóhelyként szolgáló intézmény (Carolina Óvoda és Bölcsőde) a szakvizsgával rendelkező mentoróvónők létszáma miatt jelenleg mindössze hat csoportban tud hallgatókat fogadni - a szakvizsgával rendelkező mentoróvónők létszámát növelni szükséges;

- a mentoróvónők jelentős része a nyugdíjhoz közeli korosztályhoz tartozik - fiatalítás szükséges.

\begin{tabular}{|c|c|}
\hline ERŐSSÉGEK & GYENGESÉGEK \\
\hline 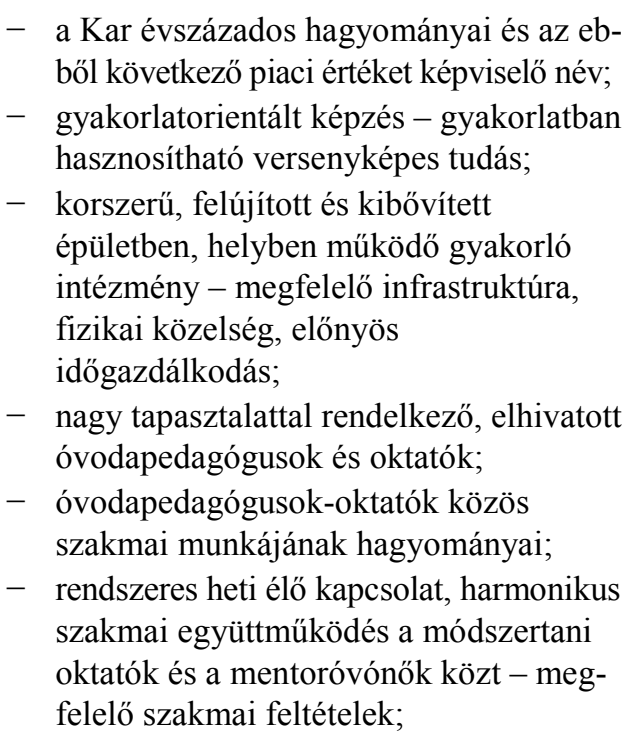 & 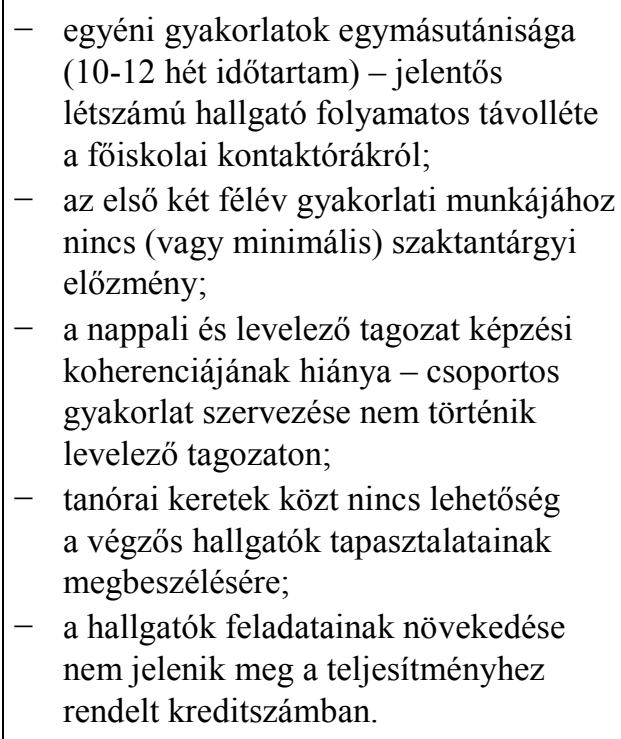 \\
\hline
\end{tabular}


- valamennyi mentoróvónő szakvizsgával rendelkezik - megfelelő személyi feltételek;

- a Comenius Karon végzett mentoróvónők magas részvételi aránya a gyakorlati képzésben - „közös nyelv”;

- a gyakorlati képzés minimum háromféle pedagógiai programú csoport munkájába enged betekintést.

\begin{tabular}{|c|c|}
\hline LEHETŐSÉGEK & VESZÉLYEK \\
\hline $\begin{array}{l}\text { - az egyéni gyakorlatok párhuzamossá } \\
\text { tétele - több óvodai csoport bevonása a } \\
\text { gyakorlati képzésbe (mentoróvónők } \\
\text { számának növelése) - ez a csoportos } \\
\text { gyakorlat újragondolását jelenti; } \\
\text { - } \text { a gyakorlati képzési struktúra } \\
\text { újragondolása. }\end{array}$ & 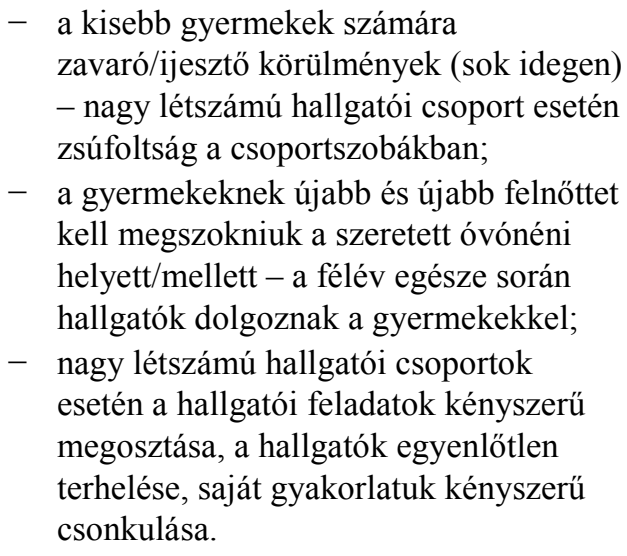 \\
\hline
\end{tabular}

\section{2. ábra: Az óvodapedagógus alapszak C-SWOT analízise 2014 tavaszán}

A továbblépés irányát ismét a képzési rendszer gyengeségei mutatják. A szervezési feladatok újragondolása mellett itt föként a tantervi hiányosságokra fókuszál a szerző (az első két félév gyakorlati munkájához nincs \{vagy minimális\} szaktantárgyi előzmény; tanórai keretek közt nincs lehetőség a végzős hallgatók tapasztalatainak megbeszélésére; a hallgatók feladatainak növekedése nem jelenik meg a teljesítményhez rendelt kreditszámban).

Az országos kitekintés és az ezt követő komparatív elemzés során az alábbi kérdésekre keresi a választ a tanulmány:

- Létezik-e valamelyest egységesnek tekinthető országos modell?

- Mennyire követi a sárospataki képzés az országos gyakorlatot?

- Mely területeken igazodunk a többség által követett struktúrához?

- Mely területeken tekinthető egyedinek a pataki képzés?

- Ez az egyediség okozott-e eddig megtapasztalt szakmai ellentmondásokat vagy problémákat? 
- E problémák orvoslására nyújt-e megoldási lehetőséget más képzőintézmények gyakorlati képzési struktúrája?

- Található-e más intézményeknél olyan elem, melynek átvétele és képzési rendszerünkbe illesztése megfontolás tárgyát képezheti?

Az országos helyzetkép bemutatására ezúttal is a képzőintézmények honlapjain elérhető gyakorlati képzési mintatantervek alapján került sor, helyenként a gyakorlati képzési kalauz (útmutató) információival kiegészítve. Továbbra is a képzési szerkezet, a szervezeti formák, a feladatok félévekre bontott ütemezése, a kreditérték és óraszám, valamint az ellenőrzés-értékelés módja állt a vizsgálat fókuszában. Az országos kitekintés során a szerző elsősorban a „pataki képzés” szempontjából fontosnak vélt szempontokat emelte ki.

Az összkreditszámot valamennyi képzőintézmény a $\mathrm{KKK}^{3}$-ban megadott értékeknek megfelelően állapította meg. Óraszám tekintetében változatosabb a kép - a féléves bontásokban nem mindig egyértelmü, hogy a képzőintézmények milyen logika alapján rendelik az óraszámokat a kreditekhez.

A nyári gyakorlat és bölcsődei hospitálás az intézmények kevesebb, mint felében szerepel, a csoportos gyakorlat (mint szervezeti forma) pedig majdnem minden második intézményben csak a 2. félévben kezdődik. Néhány intézmény külön felkészítő tréninget tart a gyakorlati képzés megkezdése előtt. Kevés képző tartja fontosnak megkülönböztetni és kiemelni a zárófoglalkozást a gyakorlati képzés elemei közül, valamint hogy lehetőséget biztosítson az összefüggő szakmai gyakorlat tapasztalatainak megbeszélésére. Az egyes tevékenységek értékelésének módja és hozzárendelt kreditértéke is nagyon eltérő a vizsgált tantervekben.

A C-SWOT analízis valamint az országos kitekintés alapján az alábbi javaslatokat fogalmazta meg a szerző a gyakorlati képzési mintatanterv megújításához (a szervezési teendőkre vonatkozó javaslatokat most nem közöljük):

- bölcsődei hospitálás bevezetése;

- a gyakorlatot kezdő hallgatók megfelelő színvonalú szakmai felkészültsége érdekében:

- továbbra is induljon az 1 . félévben a csoportos gyakorlat 1 kredit értékben; alaposan újragondolt, elötanulmányok nélkül is teljesíthető feladatokkal;

- továbbra is induljon az 1. félévben a csoportos gyakorlat 1 kredit értékben, a tanegység tartalma tréning jellegü felkészítés legyen főiskolai kontaktóra keretében;

- csak a 2. félévben kezdődjék a csoportos gyakorlat.

- a félévenkénti kreditszámok tükrözzék a feladatok növekedését;

\footnotetext{
${ }^{3}$ Képzési és kimeneti követelmény, óvodapedagógus alapképzési szak. URL: http://net.jogtar.hu/ jr/gen/hjegy_doc.cgi?docid=A0600015.OM Letöltés ideje: 2014. december 11 .
} 
- biztosítsák az összefüggő külső szakmai gyakorlatot követő tapasztalatcserét;

- a zárófoglalkozás hangsúlyosabb jelenjék meg a mintatantervben.

Mindkét alapszakunk új gyakorlati képzési struktúrájának kialakításakor törekedtünk egyfajta szakok közti koherencia megteremtésére is:

- a tájékozódás tartalmú tanegységek kredit nélküli, kritérium-követelményként való alkalmazásával;

- a záró tevékenység szerepének kiemelésével;

- a külső szakmai gyakorlatot követö önreflexió alkalmazásával.

Úgy véljük, a C-SWOT analízis, valamint az országos kitekintés és komparatív elemzés jóvoltából olyan gyakorlati képzési modulok kerültek bevezetésre a Comenius Karon a 2014/15-ös tanévben, amelyek nem csupán az eddigi hiányosságokat pótolják megnyugtatóan, hanem a kor és a pedagóguspálya újabb kihívásainak is megfelelnek.

\section{Irodalom}

Jaskóné Gácsi Mária: A gyakorlati képzés szemléleti hátterének és kereteinek meghatározása. A pedagógus-idea. Bibliotheca Comeniana XIX. - különszám, 2015 (megjelenés alatt)

Kelemen Judit: Az óvodapedagógus szakos gyakorlati képzés jelenlegi jellemzőinek vizsgálata, kritikája, országos és kari jellemzők egybevetése. Bibliotheca Comeniana XIX. - különszám, 2015 (megjelenés alatt)

Képzési és kimeneti követelmény, óvodapedagógus alapképzési szak URL: http://net.jogtar. hu/jr/gen/hjegy_doc.cgi?docid=A0600015.OM Letöltés ideje: 2014. december 11.

Képzési és kimeneti követelmény, tantó alapképzési szak. URL: http://net.jogtar.hu/jr/gen/ hjegy_doc.cgi?docid=A0600015.OM Letöltés ideje: 2014. december 11.

Marcziné Fazekas Erzsébet: Az EKF CK tanító szak gyakorlati képzésének helyzete és a képzés megújítására tett javaslatok, egybevetve az ideát szolgáló alapelvekkel. Bibliotheca Comeniana XIX. - különszám, 2015 (megjelenés alatt)

Stóka György: A szakmai gyakorlati modul az óvó- és tanitóképzés új tantervi rendszerében. Bibliotheca Comeniana XIX. - különszám, 2015 (megjelenés alatt)

Sontráné Bartus Franciska: Az óvodapedagógus és tanító ideát szolgáló gyakorlati képzés fö jellemzöinek meghatározása, alapelvek. Bibliotheca Comeniana XIX. - különszám, 2015 (megjelenés alatt) 